J. Clin. Chem. Clin. Biochem.

Vol. 22, 1984, pp. 461-466

\title{
The Measurement of Androst-4-en-17 $\beta$-ol-3,11-dione (11-Oxotestosterone) by Radioimmunoassay in Human Plasma
}

\author{
By H. K. Kley, R. Schlaghecke and H. L. Krüskemper
}

Medizinische Klinik $C$ und Poliklinik der Universität Düsseldorf

(Received October 24, 1983/March 7, 1984)

Summary: A radioimmunoassay was established for the measurement of androst-4-en-17 $\beta$-ol-3,11-dione (11-oxotestosterone). Highly specific antiserum was raised in rabbits using androst-4-en-17 $\beta$-ol-3,11-dione3 -bovine serum albumin conjugate as antigen. Cross reactivity with all steroids measured was less than $4 \%$. $\left[1,2-{ }^{3} \mathrm{H}_{2}\right]$ androst-4-en-17 $\beta$-ol-3,11-dione was synthesized from $\left[1,2-{ }^{3} \mathrm{H}_{2}\right]$ pregn-4-ene- $17 \alpha, 21$-diol-3,11,20trione in a two step reaction with $\left[1,2-{ }^{3} \mathrm{H}_{2}\right]$ androst-4-ene-3,11,17-trione as intermediate. Purification of plasma androst-4-en-17 $\beta$-ol-3,11-dione was performed by thin-layer chromatography. The intra- and interassay variation was $7.6 \%$ and $8.9 \%$, respectively. Furthermore, the radioimmunological procedure was checked against the measurement of androst-4-en-17 $\beta$-ol-3,11-dione in human plasma by gas chromatography/mass spectrometry.

Mean plasma levels of androst-4-en-17 $\beta$-ol-3,11-dione at $8 \mathrm{a}$. m. in healthy young subjects were $2.04 \pm 0.63$ $\mathrm{nmol} / 1(\overline{\mathrm{x}} \pm \mathrm{SD})$ in males and $2.18 \pm 0.89 \mathrm{nmol} / \mathrm{h}$ in females. In both groups there was a marked decrease during the night $(\mathrm{p}<0.01$ ), becoming $0.96 \pm 0.33$ and $0.96 \pm 0.40 \mathrm{nmol} / \mathrm{l}$, respectively, at 11 p.m.

Administration of human chorionic gonadotropin on 3 consecutive days did not influence the plasma concentrations of androst-4-en-17 $\beta$-ol-3,11-dione, whereas both corticotropin (from $2.35 \pm 1.12$ to $1.65 \pm 0.76$ $\mathrm{nmol} / 1 ; \mathrm{p}<0.02$ ) and dexamethasone (from $2.40 \pm 1.75$ to $0.40 \pm 0.16 \mathrm{nmol} / 1 ; \mathrm{p}<0.01$ ) caused a significant decrease of androst-4-en-17 $\beta$-ol-3,11-dione. It is concluded that androst-4-en-17 $\beta$-ol-3,11-dione appears to be an adrenal androgen in men, the physiological role of which is of considerable interest.

Radioimmunoassay zur Messung von Androst-4-en-17ß-ol-3,11-dion (11-Oxotestosteron) im Plasma des Menschen

Zusammenfassung: Ein Radioimmunassay zur Messung von Androst-4-en-17 $\beta$-ol-3,11-dion (11-Oxotestosteron) im minenschlichen Plasma wurde aufgebaut. Dazu wurde von Kaninchen ein hochspezifisches Antiserum gegen in Position 3 an Rinderserumalbumin gekoppeltes Androst-4-en-17 $\beta$-ol-3,11-dion gewonnen, dessen Kreuzreaktionen gegen alle gemessenen Steroide $<4 \%$ war. $\left[1,2-{ }^{3} \mathrm{H}_{2}\right]$ Androst-4-en-17 $\beta-3,11$-dion wurde ausgehend von $\left[1,2-{ }^{3} \mathrm{H}_{2}\right]$ pregn-4-en-17 $\alpha, 21$-diol-3,11,20-trion in einer zweistufigen Reaktion über [1,2- $\left.{ }^{3} \mathrm{H}_{2}\right]$ androst-4-en=3,11,17-trion als Zwischenprodukt synthetisiert. Vor radioimmunologischer Messung wurden die Plasmaextrakte durch Dünnschichtchromatographie gereinigt. Die Präzision der Messung von Androst-4-en-17 $\beta$-ol-3,11-dion betrug 7,6\% und 8,9\% (Intra- und Interassay-Variation). Außerdem wurde das radioimmunologische Verfahren durch die Messung von Androst-4-en-17 $\beta$-ol-3,11-dion im menschlichen Plasma mit Hilfe der Gaschromatographie/Massenspektrographie überprüft.

Die Konzentration von Androst-4-en-17 $\beta$-ol-3,11-dion im Plasma junger gesunder Männer $(n=15)$ betrug um 8 Uhr 2,04 $\pm 0,63 \mathrm{nmol} / \mathrm{h}(\overline{\mathrm{x}} \pm \mathrm{SD})$ und bei gesunden Frauen $2,18 \pm 0,89 \mathrm{nmol} / \mathrm{n}(\mathrm{n}=10)$. In beiden Gruppen bestand eine deutliche Tageszeitabhängigkeit $(p<0,01)$ mit Konzentrationen von $0,96 \pm 0,33$ (Männer) und 0,96 $\pm 0,40 \mathrm{nmol} / 1$ (Frauen) um 23.00 Uhr. Nach Applikation von HCG $(3 \times 5000$ I. E.) wurde keine Änderung der Konzentration von Androst-4-en-17 $\beta$-ol-3,11-dion gemessen, während die Gabe 
von Corticotropin (0,25 mg i.v.; Abfall um 30\%; $<<0,02)$ oder Dexamethason $(3 \mathrm{mg}$ oral am Vorabend; Abfall um $83 \% ; p<0,01$ ) eine signifikante Verminderung von Androst-4-en-17 $\beta$-ol-3,11-dion im Plasma bewirkten. Androst-4-en-17 $\beta$-ol-3,11-dion ist ein bisher im Plasma des Menschen nicht gemessenes, adrenales Androgen, dessen Bedeutung unter physiologischen und pathophysiologischen Bedingungen durch weitere Untersuchungen aufgeklärt werden muß.

\section{Introduction}

A vast number of androgens have been identified in plasma and urine (1), and many of these have a functional group at $\mathrm{C}-11(2,3)$. Since the substrate specificity of the adrenal $11 \beta$-hydroxylase (EC 1.14.15.4) is not restricted to C-21-steroids $(4,5)$, the 11 -hydroxy- and 11-oxo-androgens are believed to originate from the adrenal cortex (6). The physiological role of these androgens is still unknown in man. However, some information is available about androst-4-ene-1.1 $\beta, 17 \beta$-diol-3-one and androst-4-en$17 \beta$-ol-3,11-dione (11-oxotestosterone), which have been found in piscine plasma $(7,8,9)$. Of these androgens, androst-4-en-17 $\beta$-ol-3,11-dione appears to be the main androgen in salmonides (10), whereas in man it has not yet been measured.

Since the role of these androgens under physiological and pathological conditions have not yet been investigated in men, we established a radioimmunoassay for the measurement of androst-4-en-17 $\beta$-ol3,11-dione in human plasma. For this purpose we raised specific antibodies against androst-4-en-17 $\beta$ ol-3,11-dione in rabbits and synthesized [1,2${ }^{3} \mathrm{H}_{2}$ ]androst-4-en-17 $\beta$-ol-3,11-dione from [1,2${ }^{3} \mathrm{H}_{2}$ ]cortisone (for trivial names used see table 1 ).

\section{Materials and Methods}

\section{Chemicals and equipment}

Solvents and reagents of analytical grade were used without further purification. Phosphate buffer $(0.15 \mathrm{~mol} / 1, \mathrm{pH} 7.0)$ containing $1 \mathrm{~g} / \mathrm{l}$ gelatine served as assay buffer. Charcoal $(1 \mathrm{~g})$ and Dextran $\mathrm{T} 70(0.1 \mathrm{~g})$ were suspended in $100 \mathrm{ml}$ assay buffer. Bovine serum albumin was obtained from MERCK. UV-spectra were taken with a ZEISS-spectrometer (DM.4). Unisolve (ZINSSER, Frankfurt, Germany) was used as scintillation mixture. Tritium was measured in a liquid scintillation spectrometer (PACKARD Tricarb $460 \mathrm{C}$ ).

Nonradioactive and radioactive steroids were purchased from SIGMA and NEW ENGLAND NUCLEAR, respectively.

\section{Preparation of the androgen conjugate}

The method used to prepare androst-4-en-17 $\beta$-ol-3,11-dione-3bovine serum albumin was similar to that described by Erlanger et al. (11). The conjugate was separated from the unconjugated ste- roid by extensive dialysis against distilled water $(30 \mathrm{l}, 72 \mathrm{~h})$. Unsoluble particles were removed by centrifugation, and the supernatant was lyophylized. Androst-4-en-17 $\beta$-ol-3,11-dione-3-bovine serum albumin conjugate formation was monitored by measuring the spectra of bovine serum albumin between 200 and $300 \mathrm{~nm}$ before and after conjugation (12).

\section{Immunization procedure (13)}

Five female rabbits were immunized with $0.5 \mathrm{mg}$ of antigen emulsified in $1 \mathrm{ml}$ phosphate buffer ( $\mathrm{pH} 7.4$ ) and $1.5 \mathrm{ml}$ Freund's adjuvant (DIFCO Lab.) by intradermal injections at multiple sites. The first five injections were carried out every 14 days. Booster injections were given every 6 weeks with the same amount of antigen. The rabbits were bled at 14 day intervals after booster injections. The final dilution of antiserum used in the radioimmunoassay was 1:12000. Sera were stored at $-35^{\circ} \mathrm{C}$.

\section{Synthesis of labeled androst-4-en-17 $\beta$-ol-3,11-dione}

Radioactive androst-4-en-17ß-ol-3,11-dione is not available commercially. $\left[1,2-{ }^{3} \mathrm{H}_{2}\right]$ cortisone served as substrate for the synthesis of $\left[1,2-{ }^{3} \mathrm{H}_{2}\right]$ androst-4-en-17 $\beta$-ol-3,11-dione using the method of Appleby \& Norymberski (14): A solution of [1,2${ }^{3} \mathrm{H}_{2}$ ] cortisone ( $37 \mathrm{MBq}=1 \mathrm{mCi}$ ) in aqueous acetic acid $(1+1$ by vol.) was shaken with sodium bismuthate $(1 \mathrm{mg})$ in the dark for $1.5 \mathrm{~h}$. Steroids were extracted with ethyl acetate. After evaporation of the solvent thin-layer chromatography was performed (dichloromethane/ethanol $95+\cdot 5$ by vol.). Transformation of [1,2- $\left.{ }^{3} \mathrm{H}_{2}\right]$ cortisone to $\left[1,2-{ }^{3} \mathrm{H}_{2}\right]$ androst-4-ene-3,11,17-trione was $88 \%$. To this intermediate, dissolved in $n$-propanol $(0.2 \mathrm{ml})$, an ice-cold solution of sodium borohydride $(4 \mu \mathrm{g})$ was added, and the mixture allowed to stand for $10 \mathrm{~h}\left(4^{\circ} \mathrm{C}\right)$. Reaction was stopped by the addition of an aqueous solution of acetic acid $(20 \mathrm{~g} / 1)$. After extraction, evaporation and thin-layer chromatography, the transformation of $\left[1,2-{ }^{3} \mathrm{H}_{2}\right]$ androst-4-ene-3,11,17-trione to $[1,2-$ ${ }^{3} \mathrm{H}_{2}$ ]androst-4-en-17 $\beta$-ol-3,11-dione was found to be $47 \%$. The identity of the preparation with authentic androst-4-en-17 $\beta$-ol3,11-dione was checked by thin-layer chromatography in 2 different solvent systems (chloroform/methanol/ $/ \mathrm{H}_{2} \mathrm{O} 90+10+1$ by vol. and dichloromethane/ethanol $95+5$ by vol.). In both systems the labeled preparation used and the authentic androst-4en-17 $\beta$-ol-3,11-dione migrated identically. Furthermore, only one radioactive spot was detected using a BERTHOLD betascanner.

\section{Plasma extraction and chromatography}

Plasma samples $(1.0 \mathrm{ml})$ were mixed with labeled androst-4-en$17 \beta$-ol-3,11-dione (1500 counts/min) and allowed to equilibrate for $15 \mathrm{~min}$ at room temperature. Steroids were extracted with diethylether $(5 \mathrm{ml})$. The solvent was removed by a gentle stream of nitrogen and the residue was purified by thin-layer chromatography (MERCK silica 60 F 254 ; solvent system: cyclohexane/ethyl acetate $50+50$ by vol.). Androst-4-en-17/3-ol-3,11-dione was located from the position of chromatographed non-radioactive androst-4-en-17 $\beta$-ol-3,11-dione (detected in UV), and by betascanning of the spot. 


\section{Radioimmunoassay}

The methanolic eluates from thin-layer chromatography containing androst-4-en-17 $\beta$-ol-3,11-dione were evaporated to dryness under a stream of nitrogen and dissolved in methanol $(0.5 \mathrm{ml})$. Duplicates of $0.10 \mathrm{ml}$ were used for radioimmunoassay and a $0.20 \mathrm{ml}$ sample was taken for the measurement of procedural loss after evaporation of the solvent. To each tube (unknown samples and standards) $\left[1,2-{ }^{3} \mathrm{H}\right]$ androst-4-en-17/3-ol-3,11-dione (about 8000 counts $/ \mathrm{min}$ ) in $0.05 \mathrm{ml}$ and $0.20 \mathrm{ml}$ of antiserum-buffer dilution were added. After incubation at $4^{\circ} \mathrm{C}$ overnight, a charcoal suspension $(0.5 \mathrm{ml})$ was added to each tube. The tubes were vortexed and after a $10 \mathrm{~min}$ incubation period at $4^{\circ} \mathrm{C}$ they were centrifuged at $1500 \mathrm{~g}$ for $10 \mathrm{~min}$. Aliquots of the supernatants were placed in counting vials containing $10 \mathrm{ml}$ scintillation fluid. The procedure for the measurement of cortisol (15) and testosterone (16) was described previously.

\section{Experimental conditions}

Androst-4-en-17 $\beta$-ol-3,11-dione was measured in the plasma of healthy male $(n=15)$ and female $(n=10)$ subjects $(20-40$ years of age) at 8 a.m. and 11 p.m.

Corticotropin stimulation of the adrenal gland was carried out by i.v. injection of $0.25 \mathrm{mg}$ corticotropin (Synacthen, CIBA, Basel/ Schweiz) in 8 healthy male volunteers. Blood was taken immediately before and $1 \mathrm{~h}$ after stimulation.

Dexamethasone ( $3 \mathrm{mg}$, orally) was applied for adrenal suppression at 11 p.m. to 8 healthy female subjects. Blood samples were taken at $8 \mathrm{a} . \mathrm{m}$. on the day of dexamethasone application and at 8 a.m. the day thereafter.

Testicular stimulation was performed in 7 healthy male subjects as described previously (17). On the first and fourth day plasma was collected at $8 \mathrm{a} . \mathrm{m}$. and 7 p.m. and on the first, second and third day 5.000 I.U. human chorionic gonadotropin were administered i.m. at 7 p.m.

\section{Statistics}

Hormone concentrations were given as mean \pm standard deviation ( $\bar{x} \pm S D)$. Data were processed statistically using Student's ttest or Wilcoxon's test.

\section{Results}

Reliability criteria for the measurement of androst-4-en-17 $\beta$-ol-3,17-dione in human plasma

\section{Specificity}

The specificity of the antiserum was determined by incubation of constant amounts of antiserum and labelled antigen with varying amounts of cross-reacting steroids (tab. 1). The highest cross-reaction was $3.4 \%$.

\section{Precision}

The intra-assay coefficient of variation was $7.6 \%$ (n $=10)$, and the inter-assay coefficient of variation was $8.9 \%(n=10)$.

\section{Sensitivity}

The sensitivity was estimated using the formula of Abraham (18). The blank values for androst-4-en$17 \beta$-ol-3,11-dione were $0.010 \mathrm{pmol} /$ tube. Significant differences from zero values were obtained starting with 0.017 pmol androst-4-en-17 $\beta$-ol3,11-dione (fig. 1). After semi-logarithmic transformation the standard curves showed linearity from 0.0332 to 3.32 pmol androst-4-en-17 $\beta$-ol-3,11-dione.

\section{Accuracy}

The average recovery value of added $\left[1,2-{ }^{3} \mathrm{H}_{2}\right]$ androst-4-en-17 $\beta$-ol-3,11-dione from 83 plasma samples was $86.1 \pm 4.2 \%$. All hormone concentrations

Tab. 1. Cross-reactivities of different steroids with the antiserum to androst-4-en-17 $\beta$-ol-3,11-dione-3-bovine serum albumin conjugate.

Androst-4-en-17 $\beta$-ol-3,11-dione (11-oxotestosterone)

Androst-4-en-17 $\beta$-ol-3-one (testosterone)

$5 \alpha$-Androstan-17 $\beta$-ol-3-one (dihydrotestosterone)

Androst-4-ene-11 $\beta, 17 \beta$-diol-3-one (11-hydroxytestosterone)

Pregn-4-ene-11 $\beta, 17 \alpha, 21$-triol-3,20-dione (cortisol)

Pregn-4-ene-17 $\alpha, 21$-diol-3,11,20-trione (cortisone)

Androst-4-ène-3,17-dione (androstenedione)

$5 \alpha$-Androstane-3 $\alpha, 11 \beta$-diol-17-one

Pregn-4-ene-11 $\beta, 21$-diol-18-al-3,20-dione (aldosterone)

Androst-4-ene-3,11,17-trione

Androst-4-en-11 $\beta$-ol-3,17-dione

$5 \alpha$-Androstan-3 $\alpha$-ol-17-one (androsterone)

$5 \beta$-Androstan-3 $\alpha$-ol-17-one

$5 \beta$-Androstan-3 $\alpha$-ol-11,17-dione

Pregn-4-ene-3,20-dione (progesterone)

Pregn-4-en-17 $\beta$-ol-3,20-dione (17-hydroxyprogesterone)

Pregn-5-en-3 $\beta$-ol-20-one (pregnenolone)

Pregn-1,4-diene-9 $\alpha$-fluor-16 $\alpha$-methyl-1 $1 \beta, 17 \alpha, 21$-triol-3,20-dione (dexamethasone)

Oestra-1,3,5(10)-trien-3-ol-17-one (oestrone)

Oestra-1,3,5(10)-triene-3,16 $\alpha, 17 \beta$-triol (oestriol)
$100.00 \%$

$3.40 \%$

$2.20 \%$

$0.90 \%$

$0.27 \%$

$0.22 \%$

$0.06 \%$

$0.06 \%$

$0.06 \%$

$0.05 \%$

$0.05 \%$

$0.05 \%$

$0.04 \%$

$0.04 \%$

$0.02 \%$

$<0.01 \%$

$<0.01 \%$

$<0.01 \%$

$<0.01 \%$

$<0.01 \%$ 


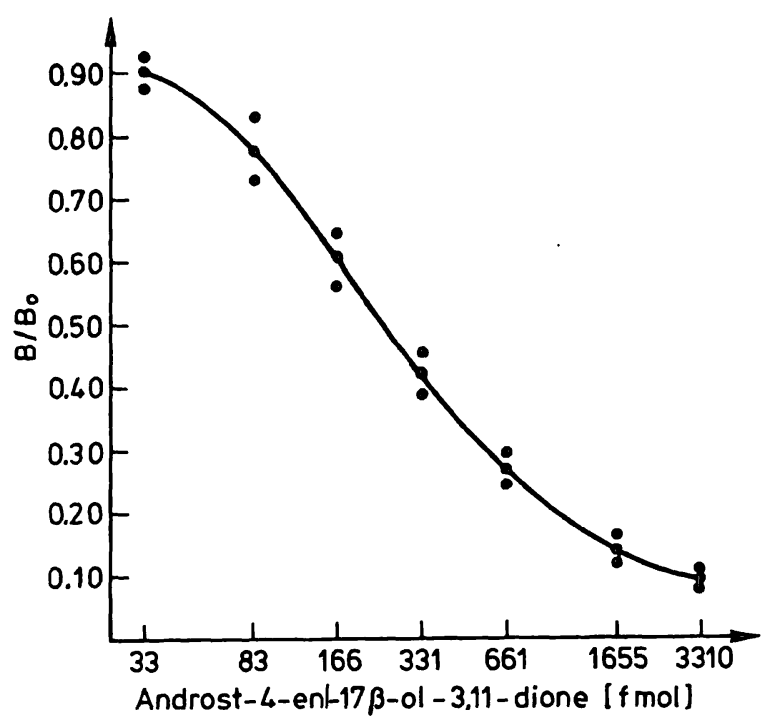

Fig. 1. Mean standard curve of androst-4-en-17 $\beta$-ol-3,11-dione (11-oxotestosterone) $(\bar{x} \pm S D)$ obtained from 10 different radioimmunoassays.

given were corrected for procedural loss using an internal standard for each sample. One ml aliquots of pooled male plasma was heated for $1 \mathrm{~h}$ at $70^{\circ} \mathrm{C}$, then cleared of endogeneous steroids by charcoal absorption. To these plasma samples, $0,66,1.32$ or 2.31 pmol of non-radioactive androst-4-en-17 $\beta$-ol-3,11dione were added. The samples were processed as usual. Comparison of the expected amounts deter- mined in the described radioimmunoassay, gave a correlation coefficient of $r=0.993$.

Furthermore, accuracy (and precision) of the radioimmunological procedure was checked against detection by gas chromatography/mass spectrometry (L. Siekmann, Bonn; see acknowledgment). For gas chromatography of the heptafluorobutyrate derivate of androst-4-en-17 $\beta$-ol-3,11-dione a capillary column (SE 30) was used. In a given sample of pool plasma the substance was identified by the mass peaks 600 and 490 . The concentration measured by radioimmunoassay was $0.795 \mathrm{nmol} / \mathrm{l}$, and 0.773 $\mathrm{nmol} / \mathrm{l}$ when determined by the physico-chemical method (difference $3 \%$ ).

Plasma concentrations of androst-4-en$17 \beta$-ol-3,17-dione

There was a marked diurnal variation of both cortisol and androst-4-en-17 $\beta$-ol-3,11-dione when measuring basal plasma concentrations (tab. 2). Concomitantly with cortisol, the concentration of androst-4en-17 $\beta$-ol-3,11-dione also decreased significantly ( $p$ $<0.01$ ) from $2.04 \pm 0.63$ in the males $(2.18 \pm 0.89$ in female subjects) to $0.96 \pm 0.53(0.96 \pm 0.40)$ $\mathrm{nmol} / \mathrm{l}$ (decrease by $55 \%$ ). No sex differences were found in the plasma concentrations of androst-4-en$17 \beta$-ol-3,11-dione at 8 a.m. or 11 p.m., respectively.

Tab. 2. Diurnal variation of plasma cortisol and plasma androst-4-en-17ß-ol-3,11-dione (nmol/l; $\bar{x} \pm$ SD) in healthy male/female subjects, 20-40 years of age. Differences in sex were not statistically significant.

\begin{tabular}{|c|c|c|c|c|c|c|}
\hline & $\begin{array}{l}\text { Males } \\
(n=15)\end{array}$ & & & $\begin{array}{l}\text { Females } \\
(n=10)\end{array}$ & & \\
\hline & 8 a.m. & 11 p.m. & $p$ & 8 a.m. & 11 p.m. & $p$ \\
\hline Cortisol & $344.7 \pm 108.7$ & $90.2 \pm 53.0$ & $<0.01$ & $302.2 \pm 92.2$ & $67.6 \pm 47.4$ & $<0.01$ \\
\hline Androst-4-en-17 $\beta$-ol-3,11-dione & $2.04 \pm 0.63$ & $0.96 \pm 0.33$ & $<0.01$ & $2.18 \pm 0.89$ & $0.96 \pm 0.40$ & $<0.01$ \\
\hline
\end{tabular}

To obtain $[\mu \mathrm{g} / 1]$ multiply by 0.362 (cortisol) or 0.302 (androst-4-en-17 $\beta$-ol-3,11-dione).

Tab. 3. Plasma cortisol and androst-4-en-17 $\beta$-ol-3,11-dione ( $\mathrm{nmol} / \mathrm{l}$ ) before and after corticotropin stimulation in 8 healthy males, $20-40$ years of age. Blood was drawn at $8 \mathrm{a} . \mathrm{m}$. and $1 \mathrm{~h}$ after $\mathrm{i}$.v. injection of $0.25 \mathrm{mg}$ corticotropin.

\begin{tabular}{llllll}
\hline & $\begin{array}{l}\text { Before } \\
\text { stimulation } \\
\text { (B) }\end{array}$ & $\begin{array}{l}\text { After } \\
\text { stimulation } \\
\text { (A) }\end{array}$ & A/B & p \\
\hline $\begin{array}{l}\text { Cortisol } \\
\begin{array}{l}\text { Androst- } \\
\text { 4-en-17 } \\
\text { ol-3,11-dione }\end{array}\end{array}$ & $222.4 \pm 80.9$ & $651.0 \pm 96.3$ & 2.94 & $<0.01$ \\
\hline
\end{tabular}

Tab. 4. Plasma cortisol and androst-4-en-17 $\beta$-ol-3,11-dione before and after adrenal suppression by dexamethasone in 8 healthy females subjects, 20-40 years of age. Blood was drawn at $8 \mathrm{a} . \mathrm{m}$. before and at $8 \mathrm{a} . \mathrm{m}$. after dexamethasone application (at 11 p.m., orally).

\begin{tabular}{|c|c|c|c|c|}
\hline & $\begin{array}{l}\text { Before } \\
\text { suppression }\end{array}$ & $\begin{array}{l}\text { After } \\
\text { suppression }\end{array}$ & & \\
\hline & (B) & $(\mathrm{A})$ & $\mathrm{A} / \mathrm{B}$ & p \\
\hline Cortisol & $262.4 \pm 93.8$ & $11.0 \pm 8.3$ & 0.042 & $<0.01$ \\
\hline $\begin{array}{l}\text { Androst- } \\
\text { 4-en-17ß- } \\
\text { ol-3,11-dione }\end{array}$ & $2.40 \pm 1.75$ & $0.40 \pm 0.16$ & 0.167 & $<0.01$ \\
\hline
\end{tabular}


After corticotropin administration cortisol increased 2.94 fold (tab. 3); in contrast to cortisol, androst-4en-17 $\beta$-ol-3,11-dione decreased by $30 \%(p<0.02)$ (difference between values before and $1 \mathrm{~h}$ after corticotropin administration).

Dexamethasone suppression of the adrenal gland caused a substantial decrease in cortisol and androst4-en-173-ol-3,11-dione $(p<0.01$ ) (tab. 4). Androst-4-en-17 $\beta$-ol-3,11-dione decreased by $83 \%$ (from $2.40 \pm 1,75$ to $0.40 \pm 0.16 \mathrm{nmol} / \mathrm{l}$ ).

Human chorionic gonadotropin stimulation over a period of 3 days in 7 male volunteers resulted in a 2fold increase in testosterone (tab. 5). Plasma androst-4-en-17 $\beta$-ol-3,11-dione, however, remained unaffected by elevated steroid sccretion of the gonads.

Tab. 5. Plasma testosterone and androst-4-en-17/-ol-3,11-dione ( $\mathrm{nmol} / \mathrm{l}$ ) before and after human chorionic gonadotropin stimulation in 7 healthy male subjects. $5.000 \mathrm{I} . \mathrm{U}$. human chorionic gonadotropin were given i.m. on 3 consecutive days at 7 p.m. Blood was drawn at 8 a.m. and at 7 p.m. on the first and the fourth day. Data represent the mean of the two samples of each day.

\begin{tabular}{lllll}
\hline & $\begin{array}{l}\text { Before } \\
\text { stimulation } \\
\text { (B) }\end{array}$ & $\begin{array}{l}\text { After } \\
\text { stimulation } \\
\text { (A) }\end{array}$ & A/B & p \\
\hline $\begin{array}{l}\text { Testosterone } \\
\begin{array}{l}\text { Androst- } \\
\text { 4-cn-17/3- } \\
\text { ol-3,11-dione }\end{array}\end{array}$ & $18.92 \pm 6.78$ & $37.95 \pm 10.87$ & 2.01 & $<0.02$ \\
\hline
\end{tabular}

To obtain [ $\mu \mathrm{g} / 1]$ multiply by 0.288 (tcstosterone) or 0.302 (androst-4-en-17ß-ol-3,11-dione).

\section{Discussion}

The development of a radioimmunoassay for the determination of androst-4-en-17\%-ol-3,11-dione is described. The antiserum was of high specificity (tab. 1). The maximal cross-reaction with other steroids was smaller than $4 \%$. Therefore the assay might have been used without chromatographical separation of other plasma steroids. The fact, however, that this particular androgen has not been quantified in human peripheral blood so far, makes it necessary to minimize any possible unspecific effects. For this reason we used thin-layer chromatography before radioimmunoassay. Furthermore, for the same reason, precision and accuracy of the method were validated by a different physico-chemical procedure. Using gas chromatography/mass spectrometry, androst-4-en-17 $\beta$-ol-3,11-dione was measured in human plasma. Moreover, both independent methods gave almost identical results when measuring plasma concentrations of a pool plasma.

The purity of the $\left[1,2-{ }^{3} \mathrm{H}_{2}\right]$ androst-4-en- $17 \beta-\mathrm{ol}-$ 3,11-dione preparation was checked in two thin laycr chromatography-systems. In both systems [1,2${ }^{3} \mathrm{H}_{2}$ ]androst-4-en-17/3-ol-3,11-dione migrated identically with authentic unlabeled androst-4-en-17/3ol-3,11-dione.

It was demonstrated that androst-4-en-17/3-ol-3,11dione is present in the plasma of male subjects in considerable amounts (about $2 \mathrm{nmol} / \mathrm{l}$ ). This range of plasma concentration is comparable with that of androst-4-ene-3,17-dione in men (19) and is even higher than that of $5 \alpha$-androstan-17/3-ol-3-one. In females androst-4-en-17 $\beta$-ol-3,17-dione cven exceeds the known average testosteronc concentration (20). However, in contrast to testosterone, no sex differences could be found for androst-4-en-17 $\beta$-ol3,11-dione.

Our data demonstrate that the androst-4-en-17 $\beta$-ol3,11-dione concentration is substantially higher in the morning (tab. 2) than in the evening, suggesting a circadian rhythm of the type already described for cortisol plasma levels. Furthermore, it was shown that dexamethasone application lowered androst-4en-17 $\beta$-ol-3,11-dione levels significantly, which was again paralleled by a fall of cortisol concentration.

Unexpectedly, corticotropin application resulted in a decrease in androst-4-en-17 $\beta$-ol-3,11-dione plasma concentrations. This phenomenon has not yet been described. Sharma et al. (21), however, were able to show that adrenal and gonadal androgens (androstenedione, androst-5-en-3 $\beta$-ol-17-one, testosterone) are effective competitive inhibitors in the conversion of 11-deoxycorticosterone (pregn-4-en-21ol-3,20-dione) to corticosterone (pregn-4-ene$11 \beta, 21$-diol-3,20-dione) in bovine adrenals; in-vivo androgen inhibition of 11/3-hydroxylase (EC 1.14.15.4) appears to be of minor importance. This is demonstrated by increased cortisol after corticotropin and the unaffected plasma values of androst4-en-17ß-ol-3,11-dione after human chorionic gonadotropin stimulation.

As demonstrated by our studics with human chorionic gonadotropin stimulation on the Leydig cells, plasma androst-4-en-17/3-ol-3,11-dione appears to depend exclusively on adrenal synthesis in male sub- 
jects, thus making this steroid a specific marker of adrenal function.

Further studies will show whether or not androst-4en-17 $\beta$-ol-3,11-dione plays a (substantial) role during maturation and ageing, as well as in pathological conditions of adrenal function.

\section{References}

1. Martin, C. R. (1976) In: Textbook of Endocrine Physiology, Williams \& Wilkins Comp. Baltimore, p. 253.

2. Goldzieher, J. W. \& Beering, S. C. (1969) J. Clin. Endocrinol. Metab. 29, 171-178.

3. Goldzieher, J. W. \& Axelrod, L. R. (1971) J. Clin. Endocrinol. Metab. 33. 176-181.

4. Hayano, H. \& Dorfman, R. J. (1962) In: Methods in Enzymology (Colowick, S. P. \& Kaplan, N. D., eds.) Vol. 5, Academic Press, New York, p. 503.

5. Meyer, A. S.,Hayano, M., Lindberg, M. C., Gut, M. \& Rogers, C. G. (1955) Acta Endocrinol. 18, 148-168.

6. Goldzieher, J. W., de la Pena, A. \& Maas Aivaliotis, M. (1978) J. Steroid Biochem. 9, 169-173.

7. Campbell, C. M., Fostier, A., Jalabert, B. \& Truscott, B. (1980) J. Endocrinol. 85, 371-378.

8. Simpson, T. H. \& Wright, R. S. (1977) Steroids 29, 383398.

9. Sangalang, G. B. \& Freeman, H. C. (1977) Gen. Comp. Endocrinol. 32, 432-443.

10. Leatherland, J. F., Copeland, P., Sumpter, J. P. \& Sonstegard, R. A. (1982) Gen. Comp. Endocrinol. 48, 196-204.

\section{Acknowledgements}

The authors would like to thank Prof. Dr. L. Siekmann, Institute of Clinical Chemistry, University of Bonn, Germany, for measuring androst-4-en-17 $\beta$-ol-3,11-dione by gas chromatography/mass spectrometry detection. Furthermore, skilled technical assistance of Mrs. Seifert, Mrs. Junker and Ms. Müller is gratefully acknowledged. This investigation was supported by the Deutsche Forschungsgemeinschaft (KI 346).

11. Erlanger, B. F. (1973) Pharmacol. Rev. 25, 271-280.

12. Erlanger, B. F., Borek, F., Beiser, G. M. \& Liebermann, S. (1957) J. Biol. Chem. 228, 713-727.

13. Vaitukaitis, J., Robbins, J. B., Nieschlag, E. \& Ross, G. T. (1971) J. Clin. Endocrinol. Metab. 33, 988-991.

14. Appleby, J. I. \& Norymberski, J. K. (1955) Biochem. J. 60 , 460-467.

15. Kley, H. K., Bartmann, E. \& Krüskemper, H. L. (1977) Acta Endocrinol. 85, 209-219.

16. Nieschlag, E. \& Loriaux, D. L. (1972) Z. Klin. Chem. 10 , 164-168.

17. Nieschlag, E., Rohr, M., Wombacher, H. \& Overzier, C. (1971) Klin. Wochenschr. 49, 91-100.

18. Abraham, G. E. (1974) Acta Endocrinol. Suppl. 183, 75.

19. Rosenfield, R. L. (1971) J. Clin. Endocrinol. Metab. 32 , 717-728.

20. Träger, L. (1977) In: Steroidhormone, Springer Verlag, New York-Heidelberg-Berlin, p. 76.

21. Dorfman, R. I. \& Ungar, F. (1965) In: Metabolism of Steroid Hormones. Academic Press, New York-London, p. 385.

Prof. Dr. H. K. Kley

Medizinische Universitätsklinik C

Moorenstraße 5

D-4000 Düsseldorf 